\title{
RECOMMENDATIONS FOR HISTOPATHOLOGY REPORT OF COLORECTAL CARCINOMA SPECIMENS
}

\author{
Alma Demirović1, Božo Krušlin ${ }^{1,2}$ \\ ${ }^{1}$ University Department of Pathology, Sestre milosrdnice University Hospital \\ Center, Zagreb, Croatia; ${ }^{2}$ Department of Pathology, School of Medicine University \\ of Zagreb, Zagreb, Croatia
}

\begin{abstract}
Summary
In the post-genomic era of medicine, histopathological assessment of colorectal carcinoma specimens plays the key role in the comprehensive management of patients with colorectal cancer. Adequate specimen handling and dissection is a crucial step in obtaining a precise and accurate pathohistologic report. Microscopic analysis must give information on: histological tumour type and differentiation, maximum extent of local invasion (pT stage), grade of tumour regression following pre-operative (neoadjuvant) therapy, resection margins (longitudinal and circumferential margins), lymph node status, venous invasion, MSI status and other abnormal findings. Latest ESMO consensus guidelines for the management of patients with metastatic colorectal cancer emphasize the pathologist' role in this process. Recently defined molecular subtypes of colorectal cancer will hopefully serve as the basis for future trials.
\end{abstract}

Keywords: colorectal carcinoma; histopathology report; adequate specimen handling; prognostic factors; predictive factors; molecular pathology.

\section{INTRODUCTION}

In the post-genomic era of medicine, histopathological assessment of colorectal carcinoma specimens plays the key role in the comprehensive management of patients with colorectal cancer. A pathological report must contain some crucial data that are essential to plan the treatment and follow-up of individual patients. $\mathrm{Cu}$ rrently valid Croatian National Guidelines for the examination and reporting of colorectal resection specimens containing carcinoma were presented at the fifth Congress of Croatian Society of Pathology and Forensic Medicine in 2012 (Zagreb) and adopted in 2016 at the sixth Congress of Croatian Society of Pathology and Forensic Medicine (Osijek) [1]. These guidelines are very thoroughly explained in a recently published paper by Jakić-Razumović [2]. This review will address some 
of the most important ones and introduce up-to-date ESMO consensus guidelines for the management of patients with metastatic colorectal cancer that are related to pathohistologic report [3].

\section{SPECIMEN HANDLING}

Adequate specimen handling and dissection is a crucial step in obtaining a precise and accurate pathohistologic report. According to the Royal College of Pathologists colorectal cancer dataset it would be ideal to receive specimens fresh and unopened as soon as possible after surgical resection. Since such a practice is hard to achieve in routine daily work it is than necessary to deliver specimens in a large volume of formaline fixative [4]. But, before a pathologist even starts to macroscopically examine and cut the specimen, he/she must be informed on the patients' medical history such as adjuvant chemo/radiotherapy, prior operations, history of inflammatory bowel disease etc. Surgical specimen is then inspected to locate the tumour and the presence of perforation if present $[2,5,6]$. After assessing proximal and distal surgical margins, the circumferential (non-peritonealised) surgical resection margin should also be assessed. If the tumor is in the vicinity of it, the circumferential margin should be inked to enable the precise microscopic identification of its involvement $[2,5,6]$. As a minimum, four blocks of tumor tissue should be taken to assess: the deepest level of tumor penetration, involvement of serosal surface, invasion of veins and involvement of any adjacent organ if present [4]. If tumor is near the circumferential resection margin, a block of tissue to show the closest approximation should also be sampled [2,4]. Serosal involvement is best identified if blocks are taken from areas that are dulled or fibrotic. At least two blocks taken from these areas are recommended [7]. Venous invasion can be suspected macroscopically as fine pale lines radiating from the base of the tumour [4]. All lymph nodes identified must be sampled. Factors influencing total lymph node harvest are numerous and can be divided in two major groups: modifiable and non-modifiable [8]. Non-modifiable factors include patients' gender, ethnicity, age, socioeconomic class, body mass index, tumour location, size, histological subtype, stage, microsatellite instability, lymph node positivity/negativity, lymphovascular invasion. Modifiable factors include tumour inking, neoadjuvant therapy, surgical technique and pathologists' engagement and knowledge while dissecting specimen [8]. The most usual and important modifiable factor influencing lymph node yield, especially in rectal cancer, is the preoperative chemo/radiotherapy and this procedure must be clearly stated [9]. The median number of lymph nodes examined should be greater than 12 [2,4]. Data regarding recommendations as to whether lymph nodes are embedded entire- 
ly are still insufficient. There are some recommendations to embed small nodes $(<4$ $\mathrm{mm}$ ) entirely and to take a single block through the longest axis of larger nodes [4]. Additionally, every other abnormal finding related to the surrounding mucosa or other structures should also be sampled.

\section{PATHOLOGICAL REPORT AND PERSONALIZED MEDICINE}

Once a pathologist has properly examined and cut all relevant tissue blocks, material is routinely processed and standard hematoxylin-eosin slides are provided and analyzed under the light microscope. Results of the microscopic analysis are, in the vast majority of cases, the very basis for the upcoming decisions regarding patients' management and follow-up. Microscopic analysis must give information on: histological tumour type and differentiation, maximum extent of local invasion (pT stage), grade of tumour regression following pre-operative (neoadjuvant) therapy, resection margins (longitudinal and circumferential margins), lymph node status, venous invasion, MSI status and other abnormal findings [2,4]. For the microscopic assessment of tumour type the WHO classification from 2010 is recommended [10]. Morphological assessment of differentiation applies only to 'Adenocarcinoma, NOS' and not to specific variants [10]. The maximum degree of local invasion into or through the bowel wall is the criterion for $\mathrm{pT}$ staging [11]. All of the above mentioned parameters are nicely described in the Croatian National Guidelines and explained in the paper by Jakić-Razumović [2]. Mismatch repair (MMR) status can be evaluated by immunohistochemistry, applying a panel of four antibodies (MLH1, PMS2, MSH2, MSH6). Tumours that are microsatellite instability-high (MSI-H) usually demonstrate mucinous or medullary differentiation [12].

Latest ESMO consensus guidelines for the management of patients with metastatic colorectal cancer emphasize the pathologist' role in this process [3]. Several recommendations regarding biomarker testing (RAS, BRAF, MSI) are published and will be concisely presented. It is stated that standardization of tissue processing of specimens obtained from patients with metastatic colorectal cancer is hard to achieve [3]. The time from tissue sampling to fixation should be minimized to a few minutes to prevent degradation of proteins and nucleic acids $[13,14]$. Fixation with $10 \%$ neutral buffered formalin is recommended and fixation time should not be less than 6 hours and no greater than 48 hours [3]. The primary pathologist should review specimens and select ones that are suitable for biomarker testing and has to ensure that a selected specimen contains sufficient quantity of neoplastic cells $[3,15]$. It is recommended that a sample should contain at least $50 \%$ of tumour versus nontumor cells [3]. Regarding RAS mutation testing, tissue from the primary tumour 
or a liver metastasis can be used for this purpose. Lymph node metastases are not suitable for RAS mutation testing. But, lung or lymph node metastases can both be used if tissue from primary tumour or liver metastasis is not available [3]. BRAF mutation testing is supposed to be assessed alongside with RAS mutation testing as it has strong prognostic value and can be potentially important for clinical trials [3]. It is stated that MSI testing can be helpful in genetic counseling. Moreover MSI status has strong predictive value for the effectiveness of immune check-point inhibitors when concerning treatment options [3].

Colorectal cancer is a heterogenous disease and none of the existing gene expression profiles have managed to accurately predict recurrence or prognosis for patients with this disease [3]. Recently, an international molecular classification has been adopted [16]. There are four molecular subtypes of colorectal cancer CMS1 (MSI Immune) - hypermutated, microsatellite unstable with strong immune activation; CMS2 (Canonical) - epithelial, chromosomally unstable, with marked WNT and MYC signaling activation; CMS3 (Metabolic) - epithelial, with metabolic dysregulation; CMS4 (Mesenchymal) - prominent TGF $\beta$ activation, stromal invasion and angiogenesis. Hopefully, this will serve as the basis for future trials.

\section{CONCLUSION}

Accurate pathology reporting of colorectal cancer resection specimen is crucial because it gives essential information that help plan the treatment of individual patients. Moreover, it contains some key prognostic parameters. Appropriate specimen handling in the operation room as well as precise macroscopic and microscopic examination performed by pathologist are vital for obtaining reliable pathohistologic report. These are also prerequisites for accurate molecular analysis. In order to achieve and maintain high-quality clinical management, it is advised to make decisions for individual patients in a multidisciplinary team.

\section{References}

[1] Hrvatsko društvo za patologiju i sudsku medicinu Hrvatskog liječničkog zbora. Prijedlog smjernica za patohistološke nalaze zloćudnih tumora. Zagreb, 2012.

[2] Jakić-Razumović J. Protocol for the primary colon and rectum carcinoma specimen examination. Rad HAZU, Medicinske znanosti. 2015;41:117-30.

[3] Van Cutsem W, Cervantes A, Adam R. ESMO consensus guidelines for the management of patients with metastatic colorectal cancer. Ann Oncol. 2016;27:1386-422.,

[4] Loughrey MB, Quirke P, Shepherd NA. The Royal College of Pathologist dataset for colorectal cancer histopathology reports, $3^{\text {rd }}$ revision, London, 2014. 
[5] Burroughs SH, Williams GT. ACP Best practice no 159. Examination of large intestine resection specimens. J Clin Pathol. 2000;53:344-9.

[6] Quirke P, Morris E. Reporting colorectal cancer. Histopathology. 2007;50:103-12.

[7] Ludeman L, Shepherd NA. Serosal involvement in gastrointestinal cancer: its assessment and significance. Histopathology. 2005;47:123-31.

[8] Wood P, Peirce C, Mulsow J. Non-surgical factors influencing lymph node yield in colon cancer. World J Gastrointest Oncol. 2016; 8:466-73.

[9] Hermanek P, Merkel S, Hohenberger W. Prognosis of rectal carcinoma after multimodal treatment: ypTNM classification and tumor regression grading are essential. Anticancer Res. 2013;33:559-66.

[10] Hamilton SR, Bosman FT, Boffetta P et al. Carcinoma of the colon and rectum. In: Bosman FT, Carniero F, Hruban RH, Theise ND, editors. WHO Classification of Tumours of the Digestive System (4th ed). Lyon: IARC Press, 2010.

[11] Sobin L, Gospodarowicz M, Wittekind C. TNM Classification of Malignant Tumours, seventh edition. UICC. 2009.

[12] Young J, Simms LA, Biden KG et al. Features of colorectal cancers with high-level microsatellite instability occurring in familial and sporadic settings: parallel pathways of tumorigenesis. Am J Pathol. 2001;159:2107-16.

[13] Neumeister VM, Anagnostou V, Siddiqui S et al. Quantitative assessment of effect of preanalytic cold ischemic time on protein expression in breast cancer tissues. J Natl Cancer Inst. 2012;104:1815-24.

[14] Portier BP, Wang Z, Downs-Kelly E et al. Delay to formalin fixation "cold ischemia time": effect on ERBB2 detection by in-situ hybridization and immunohistochemistry. Mod Pathol. 2013;26:1-9.

[15] van Krieken JH, Jung A, Kirchner T et al. KRAS mutation testing for predicting response to anti-EGFR therapy for colorectal carcinoma: proposal for an European quality assurance program. Virchows Arch. 2008;453:417-31.

[16] Guinney J, Dienstmann R, Wang B et al. The consensus molecular subtypes of colorectal cancer. Nat Med. 2015;21:1350-6. 


\section{Sažetak}

\section{Preporuke za patohistološki pregled i nalaz uzoraka debelog crijeva s karcinomom}

U post-genomskoj eri medicine, patohistološka procjena uzoraka karcinoma debelog crijeva i dalje igra ključnu ulogu u cjelovitom i kvalitetnom pristupu pacijentima oboljelima od ove bolesti. Odgovarajuće postupanje sa samim uzorkom temelj je za dobivaje cjelovitog i svrsishodnog patohistološkog nalaza. Mikroskopska analiza mora dati podatke o: histološkom tipu tumora i gradusu, lokalnoj proširenosti (pT stadij), gradusu regresije tumora nakon neoadjuvantne terapije, resekcijskim rubovima (proksimalnom, distalnom i radijalnom), statusu limfnih čvorova, vaskularnoj invaziji, MSI statusu i ostalim patološkim nalazima ako postoje. U najnovijim ESMO smjernicama, a koje se odnose na upute o postupanju s pacijentima koji imaju metastatski kolorektalni karcinom, naglašena je važna uloga patologa u ovome procesu. Nedavno definirani molekularni podtipovi kolorektalnog karcinoma pružaju bazu za buduća istraživanja.

Ključne riječi: kolorektalni karcinom; patohistološki nalaz; odgovarajuće postupanje uzorkom; prognostički čimbenici; prediktivni čimbenici; molekularna patologija.

Corresponding author:

Alma Demirović

e-mail: alma.demirovic@kbcsm.hr 